\title{
CLONIDINE PREMEDICATION AS A DESIRABLE PART OF HYPOTENSIVE ANAESTHESIA FOR FUNCTIONAL ENDOSCOPIC SINUS SURGERY
}

\author{
V. A. Praveen ${ }^{1}$ R. Krishna Prabu² \\ ${ }^{1}$ Assistant Professor, Department of Anaesthesiology, Sri Venkateshwaraa Medical College Hospital and Research Institute. \\ ${ }^{2}$ Associate Professor, Department of Anaesthesiology, Sri Venkateshwaraa Medical College Hospital and Research Institute.
}

\begin{abstract}
BACKGROUND

Clonidine an ideal agent for hypotensive anaesthesia, also attenuates stress response to laryngoscopy, decreases requirement of inhalational anaesthetic agents, decreases postoperative analgesic requirements, prevents post-operative shivering.

\section{MATERIAL AND METHODS}

60 patients under 16-60 years age group posted for functional endoscopic sinus surgery (FESS) were randomly divided into 2 groups of 30 each. Placebo group (Group P) received $20 \mathrm{~mL}$ normal saline intravenously and Clonidine group (Group C) received 2.5 micrograms Clonidine per kilogram body weight in $20 \mathrm{~mL}$ saline intravenously 20 mins before surgery. Haemodynamic variability during surgery, intraoperative inhalational agent requirement and perioperative bleeding as assessed by surgeon, postoperative analgesic requirement and post-operative shivering were compared between two groups.
\end{abstract}

\section{RESULTS}

There was statistically significant reduction in heart rate, systolic blood pressure, diastolic blood pressure and mean blood pressure in Group C compared to Group P. There was statistically significant decrease in requirement of Isoflurane, decreased bleeding from surgical site, decreased analgesic consumption and nil incidence of postoperative shivering in Group C compared to Group P.

\section{CONCLUSION}

Clonidine is an ideal agent for hypotensive anaesthesia as it has got other favourable effects along with controlled hypotension, as it was observed in this study.

\section{KEYWORDS}

Clonidine, Hypotensive Anesthesia, Inhalational Agents, Shivering, Analgesia.

HOW TO CITE THIS ARTICLE: Praveen VA, Prabu RK. Clonidine premedication as a desirable part of hypotensive anaesthesia for functional endoscopic sinus surgery. J.Evolution Med. Dent. Sci. 2016;5(35):2014-2017, DOI: 10.14260/jemds/2016/473

\section{INTRODUCTION}

Anaesthesia for functional endoscopic sinus surgery is a challenging job. The surgeons operating field itself is very small and surrounded with mucous membranes. It is imperative for the surgeons to look at a clear surgical field in order to identify the diseased tissue properly. ${ }^{1}$ By inducing hypotension, bleeding from surgical field can be reduced thereby providing a clear surgical field. ${ }^{2}$ Clonidine is drug which is well known for its hypotensive property within good safety profile.

In our study, we have studied the other effects of Clonidine along with the hypotensive property. ${ }^{3}$ The effects of Clonidine on requirement of Isoflurane, requirement of other vasodilators, bleeding from surgical site, analgesic consumption and post-operative shivering were compared with the placebo group.

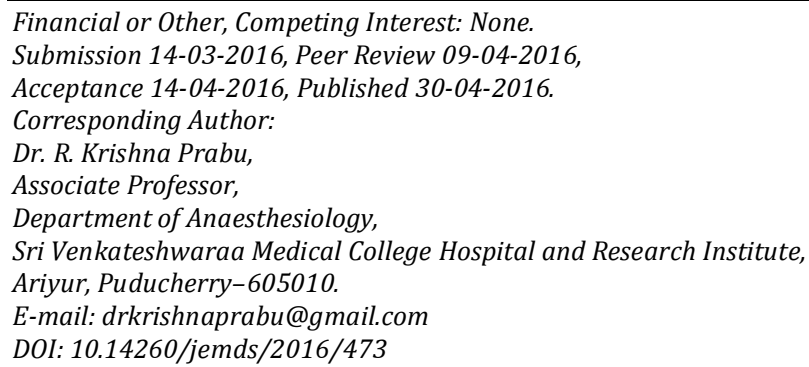

\section{MATERIAL AND METHODS}

This study was conducted after getting Institute's Scientific and Ethical Committee approval. 60 participants were included in the study after obtaining informed consent. They were randomly divided into two groups of 30 each. Patients belonging to American Society of Anaesthesiologists (ASA) class 1 and 2, patients between ages 16 to 60 and patients undergoing FESS were included in the study. Patients with history of hypertension, cerebrovascular accident, ischaemic heart disease, poor respiratory reserve, hepatic and renal dysfunction were excluded from the study.

Two 18G IV lines were started. Patients were monitored with ECG, pulse oximeter, non-invasive blood pressure, temperature and end-tidal carbon dioxide. All the patients were preloaded with $500 \mathrm{~mL}$ normal saline before induction. Nasal packing was done with $4 \%$ lignocaine with 1:200000 adrenaline. Patients in Group P received normal saline $20 \mathrm{~mL}$ intravenously and patients in Group C received 2.5 micrograms (mcg) per kg body weight of Clonidine in $20 \mathrm{~mL}$ saline intravenously. Patients were pre-oxygenated for 5 minutes. Anaesthesia was induced with glycopyrrolate 0.2 $\mathrm{mg}$, fentanyl $2 \mathrm{mcg} / \mathrm{kg}$, Xylocard $1 \mathrm{mg} / \mathrm{kg}$, propofol $2.5 \mathrm{mg} / \mathrm{kg}$ and vecuronium $0.1 \mathrm{mg} / \mathrm{kg}$. Endotracheal intubation was done orally with appropriate size tube. Anaesthesia was maintained with $66 \%$ nitrous oxide, $33 \%$ oxygen, $0.75 \%$ isoflurane and vecuronium. 
The plan was to maintain the mean arterial pressure (MAP) of $70 \mathrm{mmHg}$. If the MAP goes above, then to increase the isoflurane up to $1 \%$. If still high, then to switch over to nitroglycerin (NTG) infusion to achieve target MAP. Intraoperative hypotension was managed with fluids, ephedrine after cutting off NTG infusion. Intraoperative tachycardia was controlled using intravenous metoprolol 1-5 mg. Intravenous bradycardia was managed with Inj. Atropine $0.6 \mathrm{mg}$. At the end of the procedure, standard reversal with neostigmine $50 \mathrm{mcg} / \mathrm{kg}$ and glycopyrrolate $8 \mathrm{mcg} / \mathrm{kg}$ was done. Patients were extubated on table.

\section{The Following Parameters were Studied:}

1. Heart rate, systolic blood pressure, diastolic blood pressure, mean blood pressure were recorded during 5 perioperative stages i.e. before induction, after induction, after intubation, intraoperative average, immediate postoperative period.

2. Requirement of isoflurane and nitroglycerin to achieve target hypotension. High requirement-patients requiring $1 \%$, Moderate -0.75 to $1 \%$, Low $-<0.75 \%$.

3. Postoperative sedation score.

4. Incidence of postoperative shivering.

5. Intraoperative problems (hypotension, hypertension, arrhythmias, tachycardia, bradycardia, ischaemia).

6. Assessment of operating condition by surgeon.

7. Postoperative analgesic request time.

8. Post anaesthesia discharge criteria.

Statistical Analysis and Results

The age, sex, weight parameters were comparable.

\begin{tabular}{|c|c|c|c|}
\hline \multicolumn{4}{|c|}{ Heart Rate in Beats Per Minute } \\
\hline & Group p & Group c & p Value \\
\hline Before induction & $100 \pm 17$ & $79 \pm 20$ & 0.001 \\
\hline After induction & $98 \pm 17$ & $72 \pm 13$ & 0.000 \\
\hline After intubation & $102 \pm 17$ & $72 \pm 14$ & 0.000 \\
\hline Average intra-op & $83 \pm 4$ & $70 \pm 3$ & 0.000 \\
\hline Immediate post-op & $102 \pm 6$ & $78 \pm 3$ & 0.003 \\
\hline \multicolumn{4}{|c|}{ Table 1: Heart Rate } \\
\hline
\end{tabular}

There is statistically significant reduction in heart rate in the group $\mathrm{C}$ compared to group $\mathrm{P}$ in all the 5 perioperative stages. i.e. before induction, after induction, after intubation, intraoperative average, immediate postoperative period.

\begin{tabular}{|c|c|c|c|}
\hline \multicolumn{4}{|c|}{ Systolic Pressure in mmHg } \\
\hline & Group P & Group C & p Value \\
\hline Before induction & $130 \pm 17$ & $108 \pm 14$ & 0.000 \\
\hline After induction & $113 \pm 17$ & $95 \pm 14$ & 0.004 \\
\hline After intubation & $107 \pm 20$ & $95 \pm 6$ & 0.078 \\
\hline Average intra-op & $91 \pm 4$ & $89 \pm 5$ & 0.482 \\
\hline Immediate post-op & $127 \pm 8$ & $107 \pm 3$ & 0.030 \\
\hline \multicolumn{4}{|c|}{ Table 2: Systolic Blood Pressure } \\
\hline
\end{tabular}

There is statistically significant reduction in systolic blood pressure in the group $\mathrm{C}$ compared to group $\mathrm{P}$ before induction, after induction, and immediate postoperative period.

\begin{tabular}{|c|c|c|c|}
\hline \multicolumn{4}{|c|}{ Diastolic pressure in mmHg } \\
\hline & Group P & Group C & p Value \\
\hline Before induction & $89 \pm 12$ & $71 \pm 11$ & 0.000 \\
\hline After induction & $75 \pm 12$ & $64 \pm 13$ & 0.001 \\
\hline After intubation & $81 \pm 13$ & $62 \pm 4$ & 0.059 \\
\hline Average intra-op & $62 \pm 3$ & $61 \pm 3$ & 0.293 \\
\hline Immediate post-op & $85 \pm 5$ & $75 \pm 3$ & 0.046 \\
\hline \multicolumn{4}{|c|}{ Table 3: Diastolic Blood Pressure } \\
\hline
\end{tabular}

There is statistically significant reduction in diastolic blood pressure in the group $\mathrm{C}$ compared to group $\mathrm{P}$ before induction, after induction, and immediate postoperative period.

\begin{tabular}{|c|l|l|l|}
\hline \multicolumn{5}{|c|}{ Mean Arterial Pressure in mmHg } \\
\hline & Group P & Group C & p Value \\
\hline Before induction & $101 \pm 15$ & $82 \pm 11$ & 0.000 \\
\hline After induction & $86 \pm 22$ & $73 \pm 13$ & 0.085 \\
\hline After intubation & $90 \pm 15$ & $74 \pm 5$ & 0.066 \\
\hline Average intra-op & $69 \pm 3$ & $72 \pm 3$ & 0.382 \\
\hline Immediate post-op & $100 \pm 7$ & $85 \pm 3$ & 0.044 \\
\hline \multicolumn{4}{|c|}{ Table 4: Mean Arterial Pressure } \\
\hline
\end{tabular}

There is statistically significant reduction in mean arterial pressure in the group $\mathrm{C}$ compared to group $\mathrm{P}$ before induction and in immediate postoperative period.

\begin{tabular}{|c|c|c|c|}
\hline & $\begin{array}{c}\text { High } \\
\text { Requirement }\end{array}$ & $\begin{array}{c}\text { Moderate } \\
\text { Requirement }\end{array}$ & $\begin{array}{c}\text { Low } \\
\text { Requirement }\end{array}$ \\
\hline $\begin{array}{c}\text { Placebo } \\
\text { Group }\end{array}$ & $60 \%$ & $40 \%$ & 0 \\
\hline $\begin{array}{c}\text { Clonidine } \\
\text { Group }\end{array}$ & 0 & $10 \%$ & $90 \%$ \\
\hline \multicolumn{2}{|c|}{ Table 5: Intraoperative Requirement of Isoflurane } \\
\hline
\end{tabular}

In group $\mathrm{P}, 40 \%$ of the patients had moderate and $60 \%$ had high requirement of isoflurane. In the group $\mathrm{C}$, there were only $10 \%$ who had moderate requirement of isoflurane and $90 \%$ of the patients had only low requirement.

\begin{tabular}{|c|c|}
\hline Placebo Group & $60 \%$ \\
\hline Clonidine Group & $0 \%$ \\
\hline Table 6: Intraoperative Requirement of Nitroglycerin \\
\hline
\end{tabular}

$60 \%$ of the patients in group $\mathrm{P}$ required nitroglycerin intraoperatively and none of the patients in group $\mathrm{C}$ required nitroglycerin intraoperatively.

\begin{tabular}{|c|c|c|c|c|c|}
\hline \multirow{2}{*}{$\begin{array}{c}\text { Intraoperative } \\
\text { Problems }\end{array}$} & \multicolumn{2}{|c|}{$\begin{array}{l}\text { Placebo } \\
\text { (P) }\end{array}$} & \multicolumn{2}{|c|}{$\begin{array}{l}\text { Clonidine } \\
\text { (C) }\end{array}$} & \multirow{2}{*}{$\begin{array}{c}\text { P- } \\
\text { Value }\end{array}$} \\
\hline & NO. & $\%$ & NO. & $\%$ & \\
\hline $\begin{array}{l}\text { Arrhythmia } \\
\text { Yes } \\
\text { No }\end{array}$ & $\begin{array}{c}0 \\
30\end{array}$ & $\begin{array}{c}0 \\
100\end{array}$ & $\begin{array}{c}0 \\
30\end{array}$ & $\begin{array}{c}0 \\
100\end{array}$ & \\
\hline $\begin{array}{c}\text { Hypotension } \\
\text { Yes } \\
\text { No }\end{array}$ & $\begin{array}{c}6 \\
24\end{array}$ & $\begin{array}{l}20 \\
80\end{array}$ & $\begin{array}{l}10 \\
20\end{array}$ & $\begin{array}{l}33 \\
67\end{array}$ & 0.04 \\
\hline $\begin{array}{c}\text { Hypertension } \\
\text { Yes } \\
\text { No } \\
\end{array}$ & $\begin{array}{r}6 \\
24 \\
\end{array}$ & $\begin{array}{l}20 \\
80\end{array}$ & $\begin{array}{c}4 \\
24\end{array}$ & $\begin{array}{l}13 \\
87\end{array}$ & 1.0 \\
\hline $\begin{array}{c}\text { Tachycardia } \\
\text { Yes } \\
\text { No }\end{array}$ & $\begin{array}{c}28 \\
2\end{array}$ & $\begin{array}{c}94 \\
6\end{array}$ & $\begin{array}{c}0 \\
30\end{array}$ & $\begin{array}{c}0 \\
100\end{array}$ & \\
\hline $\begin{array}{c}\text { Bradycardia } \\
\text { Yes } \\
\text { No }\end{array}$ & $\begin{array}{c}2 \\
28\end{array}$ & $\begin{array}{c}7 \\
93\end{array}$ & $\begin{array}{c}2 \\
28\end{array}$ & $\begin{array}{c}7 \\
93\end{array}$ & 0.60 \\
\hline Table 7 & oper & ive & erse & ents & \\
\hline
\end{tabular}

In the group $\mathrm{C}$, five cases developed hypotension and two developed hypertension. The incidence of bradycardia 
was one in both the groups. Intraoperative tachycardia, arrhythmias and ischaemia were not seen in both the groups.

\begin{tabular}{|c|c|c|c|c|}
\hline \multicolumn{2}{|c|}{$\begin{array}{c}\text { Operating } \\
\text { Field }\end{array}$} & $\begin{array}{c}\text { Placebo } \\
\text { Group(P) }\end{array}$ & $\begin{array}{l}\text { Clonidine } \\
\text { Group (C) }\end{array}$ & Total \\
\hline & Excellent & 14 & 16 & 30 \\
\hline & Good & 16 & 14 & 30 \\
\hline Total & & 30 & 30 & 60 \\
\hline
\end{tabular}

\begin{tabular}{|c|c|c|c|}
\hline & Value & $\begin{array}{c}\text { Degree of } \\
\text { freedom }\end{array}$ & P value \\
\hline $\begin{array}{c}\text { Pearson Chi- } \\
\text { Square }\end{array}$ & 1.616 & 2 & .446 \\
\hline Likelihood Ratio & 1.628 & 2 & .443 \\
\hline No of valid Cases & 60 & \\
\hline Table 9: Evaluation of Operating Condition by Surgeons: \\
Chi Square \\
\hline
\end{tabular}

21 patients in group $\mathrm{C}$ and 9 patients in group $\mathrm{P}$ had excellent operating conditions as assessed by the surgeon.

\begin{tabular}{|c|c|c|c|c|}
\hline & & $\begin{array}{c}\text { Placebo } \\
\text { Group(p) }\end{array}$ & $\begin{array}{c}\text { Clonidine } \\
\text { Group(c) }\end{array}$ & Total \\
\hline $\begin{array}{c}\text { Postoperative } \\
\text { Shivering }\end{array}$ & No & 21 & 30 & 51 \\
\cline { 2 - 5 } & Yes & 9 & 0 & 9 \\
\hline Total & & $\mathbf{3 0}$ & $\mathbf{3 0}$ & $\mathbf{6 0}$ \\
\hline \multicolumn{4}{|c}{ Table 10: Post-operative Shivering } \\
\hline
\end{tabular}

\begin{tabular}{|c|c|c|c|}
\hline & Value & $\begin{array}{c}\text { Degree } \\
\text { of } \\
\text { Freedom }\end{array}$ & p value \\
\hline Pearson chi-square & 8.445 & 2 & .015 \\
\hline Likelihood ratio & 12.386 & 2 & .002 \\
\hline No. Of valid cases & 60 & & \\
\hline \multicolumn{2}{|c|}{ Table 11: Post-operative Shivering } \\
\hline
\end{tabular}

$35 \%$ of patients in group $\mathrm{P}$ and none in group $\mathrm{C}$ developed postoperative shivering.

\begin{tabular}{|c|c|c|c|c|}
\hline & & $\begin{array}{c}\text { Placebo } \\
\text { Group } \\
\text { (p) }\end{array}$ & $\begin{array}{l}\text { Clonidine } \\
\text { Group } \\
\text { (c) }\end{array}$ & Total \\
\hline \multirow{4}{*}{ Post-op sedation score } & 2 & 8 & 5 & 13 \\
\hline & 3 & 4 & 10 & 14 \\
\hline & 4 & 16 & 15 & 31 \\
\hline & 5 & 2 & 0 & 2 \\
\hline Total & & 30 & 30 & 60 \\
\hline \multicolumn{5}{|c|}{ Table 12: Post-operative Sedation Score } \\
\hline
\end{tabular}

\begin{tabular}{|c|c|c|c|}
\hline & Value & $\begin{array}{c}\text { Degree of } \\
\text { Freedom }\end{array}$ & $\begin{array}{c}\text { P } \\
\text { Value }\end{array}$ \\
\hline Pearson chi-square & 10.526 & 6 & .104 \\
\hline Likelihood ratio & 11.863 & 6 & .065 \\
\hline $\begin{array}{c}\text { Linear-by-linear } \\
\text { association }\end{array}$ & .164 & 1 & .685 \\
\hline No. of valid cases & 60 & & \\
\hline \multicolumn{2}{|c|}{ Table 13: Post-operative Sedation Score } \\
\hline
\end{tabular}

There was no statistical difference in postoperative sedation score between two groups.

\begin{tabular}{|c|c|c|c|}
\hline $\begin{array}{c}\text { Analgesia } \\
\text { Request }\end{array}$ & $\begin{array}{c}\text { Placebo } \\
\text { Group(p) }\end{array}$ & $\begin{array}{c}\text { Clonidine } \\
\text { Group(c) }\end{array}$ & P-value \\
\hline
\end{tabular}

\begin{tabular}{|c|c|c|c|}
\hline No. of cases & 30 & 30 & \multirow{3}{*}{$<0.001$} \\
\hline Mean & 0.2 & 6.4 & 1.54 \\
\hline S.D. & 0.37 & 7 \\
\hline Median & 0 & 7 & \\
\hline Mode & 0 & $2-8$ & \\
\hline Range & $0-1$ & Table 14: Time for Analgesia Request: \\
(Hours After Extubation)
\end{tabular}

The median time for request of analgesics was 7 hours in group $\mathrm{C}$ compared to less than one hour in group $\mathrm{P}$.

\begin{tabular}{|c|c|c|c|c|c|}
\hline PADSS - 6 PM & \multicolumn{2}{|c|}{ Placebo(p) } & \multicolumn{2}{|c|}{ Clonidine(c) } & \multirow{2}{*}{ P-value } \\
\cline { 2 - 5 } on day of Surgery & No. & $\%$ & No. & $\%$ & \\
\hline 6 & 0 & 0 & 5 & 16.6 & \\
7 & 8 & 26.6 & 25 & 83.4 & \\
8 & 18 & 60 & 0 & 0 & $<0.001$ \\
9 & 4 & 13.4 & 0 & 0 & \\
\hline
\end{tabular}

\begin{tabular}{|c|c|c|c|c|c|}
\hline \multirow{2}{*}{ PADSS - 6 AM } & \multicolumn{2}{|c|}{$\begin{array}{c}\text { Placebo } \\
\text { (P) }\end{array}$} & \multicolumn{2}{c|}{$\begin{array}{c}\text { Clonidine } \\
\text { (C) }\end{array}$} & \multirow{2}{*}{ p-Value } \\
\cline { 2 - 5 } & No. & $\%$ & No. & $\%$ & \\
\hline 7 & 3 & 10 & 3 & 10 & \\
8 & 0 & 0 & 0 & 0 & \\
9 & 18 & 60 & 27 & 90 & 0.01 \\
10 & 9 & 30 & 0 & 0 & \\
\hline \multicolumn{6}{|c|}{ Table 16: PADSS - 18 Hours Post-operative } \\
\hline
\end{tabular}

Only $10 \%$ of cases in group P were fit to get discharged on the day of surgery, but majority of the patients in both the group were fit to be discharged in the next day. There was no statistical difference in these criteria. So, Clonidine provides satisfactory hypotension, better operating condition, attenuates intubation response, prevents postoperative shivering, prolongs analgesia, decreases requirement of Isoflurane and nitroglycerin, without affecting the recovery.

\section{DISCUSSION}

Functional endoscopic sinus surgery (FESS) is associated with significant bleeding that impairs recognition of fine structures which negatively affects outcome. Hypotensive anaesthesia decreases blood loss, reduces surgical time and improves operation theatre resources. ${ }^{4}$

The primary goal of hypotensive anaesthesia is not only to provide bloodless surgical field but also to conduct a balanced anaesthesia and prompt recovery. Sodium nitroprusside, nitroglycerin, trimetaphan, adenosine, remifentanil, beta-blockers, ACE inhibitors, alpha-2 adrenergic agonists were tried for hypotensive anaesthesia so far in which alpha- 2 adrenergic agonists has got proven safety and recovery profile. 5 Dexmedetomidine and clonidine are common alpha adrenergic agonists used for hypotensive anaesthesia. But compared to clonidine, dexmedetomidine is costlier and has got side effects like bradycardia, dry mouth and sedation. ${ }^{6}$ Clonidine has been tried in oral as well as intravenous route for premedication in hypotensive anaesthesia.

Oral clonidine premedication was tried in some surgeries to achieve hypotensive anaesthesia for reduction of blood loss. But the results were unsatisfactory. ${ }^{7}$

Intravenous clonidine given in dose up to 4 micrograms per kilogram body weight/kg B.W (mics/kg B.W.) had produced satisfactory and reliable hypotension in patients undergoing middle ear and nasal surgeries. ${ }^{2}$ Studies have 
compared three doses of intravenous clonidine. 2 mics $/ \mathrm{kg}, 3$ mics/kg B.W, 5 mics/kg B.W. 2 mics/kg doses provided less analgesia and stable haemodynamics. 5 mics $/ \mathrm{kg}$ dose provided intense analgesia but hypotension in the postoperative period. $3 \mathrm{mics} / \mathrm{kg}$ dose has provided optimum analgesia with stable haemodynamics. ${ }^{8}$ In our study, we have used 2.5 mics $/ \mathrm{kg}$ B.W. of clonidine with which we had reliable hypotension and decreased blood loss from surgical field. The effects are titratable and the side effects of Clonidine are easily manageable. Clonidine also produces lesser episodes of tachycardia and hypertension and provides lower heart rate and blood pressure. ${ }^{9}$

Clonidine apart from an adjuvant for hypotensive anaesthesia had also got other advantages. Clonidine compared to placebo group attenuates pressor response to laryngoscopy. 10 Preoperative clonidine premedication also reduces the requirement of narcotics and inhalational anaesthetics significantly. Without Clonidine it is mandatory to go up on concentrations of inhalational anaesthetics and narcotics to achieve desired hypotensive levels. ${ }^{11,12}$ In our study, there was significant decrease in requirement of inhalational anaesthetics compared to placebo group.

Clonidine premedication also decreases the need for vasodilators along with inhalational agents to achieve desired hypotension. ${ }^{13}$ In our study, the placebo group required vasodilators to achieve hypotension in few cases. But none of the patients in clonidine group required vasodilators. Clonidine is a safe agent for hypotensive anaesthesia as it does not cause myocardial ischaemia or arrhythmias. There were no significant intraoperative adverse effects in patients who had received intravenous Clonidine in our study. ${ }^{14}$ There was minimal bleeding from the surgical site and the field was clear for the surgeon to operate. This parameter was assessed in our study by the surgeon. Clonidine, if used in appropriate doses, has no effect on recovery from general anaesthesia. ${ }^{15}$ Alpha-2 adrenergic agents has got another advantage in prevention of shivering in the postoperative period due to intraoperative hypothermia. ${ }^{16}$ In our study, there was no incidence of shivering in the postoperative period in the Clonidine group. Clonidine also prolongs the postoperative analgesia. ${ }^{17,18}$ In our study, there was significant increase in duration of postoperative analgesia and decreased analgesic requirements in clonidine group compared to placebo group. Studies show that there was no significant change in postanaesthesia discharge time in patients who had received intravenous Clonidine which was analysed using Aldrete score. ${ }^{19}$ In our study, there was no significant difference in mean discharge time for both the groups.

\section{CONCLUSION}

Clonidine apart from its hypotensive property, attenuates pressor response to laryngoscopy, decreases requirement of inhalational anaesthetics, prolongs postoperative analgesia and prevents postoperative shivering without much effect on recovery from anaesthesia.

\section{REFERENCES}

1. Stammberger H. Endoscopic endonasal surgery-concepts in treatment of recurring rhino sinusitis. Otolaryngol Head Neck Surg 1986;94(2):147-56.

2. Ramachandran S, Lakra AM, Shah PJ, et al. Effect of intravenous clonidine premedication for the bloodless surgical field in patients undergoing middle ear or nasal surgery: a comparison of three different doses. Anesth Essays Res 2015;9(3):397-400.

3. Maroof M, Khan RM, Bhatti TH. Clonidine premedication for induced hypotension with total intravenous anaesthesia for middle ear surgery. Can J Anaesth 1994;41(2):164-5.

4. Cardesin A, Pontes C, Rosell R, et al. Hypotensive anaesthesia and bleeding during endoscopic sinus surgery: an observational study. Eur Arch Otorhinolaryngol 2014;271(6):1505-11.

5. Degoute CS. Controlled hypotension: a guide to drug choice. Drugs 2007;67(7):1053-76.

6. Liu ZX, Xu FY, Liang X, et al. Efficacy of dexmedetomidine on postoperative shivering: a meta-analysis of clinical trials. Can J Anaesth 2015;62(7):816-29.

7. Taghipour Anvari Z, Afshar-Fereydouniyan N, Imani F, et al. Effect of clonidine premedication on blood loss in spine surgery. Anesth Pain Med 2012;1(4):252-6.

8. Marinangeli F, Ciccozzi A, Donatelli F, et al. Clonidine for treatment of postoperative pain: a dose-finding study. Eur J Pain 2002;6(1):35-42.

9. Myles PS, Hunt JO, Holdgaard HO, et al. Clonidine and cardiac surgery: haemodynamic and metabolic effects, myocardial ischaemia and recovery. Anaesth Intensive Care 1999;27(2):137-47.

10. Arora S, Kulkarni A, Bhargava AK. Attenuation of hemodynamic response to laryngoscopy and orotracheal intubation using intravenous clonidine. J Anaesthesiol Clin Pharmacol 2015;31(1):110-4.

11. Lessard MR, Trepanier CA, Baribault JP. Isoflurane induced hypotension in orthognathic surgery. Anesth analg 1989;69(3):379-83.

12. Engelman E, Lipszyc M, Gilbart E, et al. Effects of clonidine on anesthetic drug requirements and hemodynamic response during aortic surgery. Anesthesiology 1989;71(2):178-87.

13. Srivastava U, Dupargude AB, Kumar D, et al. Controlled hypotension for functional endoscopic sinus surgery: comparison of esmolol and nitroglycerin. Indian J Otolaryngol Head Neck Surg 2013;65(2):440-4.

14. Wijeysundera DN, Bender JS, Beattie WS. Alpha-2 adrenergic agonists for the prevention of cardiac complications among patients undergoing surgery. Cochrane Database Syst Rev 2009;(4):CD004126.

15. Bellaiche. Clonidine does not delay recovery from anaesthesia. Anesthesiology 1995;65:549-55.

16. Buggy D, Higgins P, Moran C, et al. Clonidine at induction reduces shivering after general anaesthesia. Can J Anaesth 1997;44(3):263-7.

17. Lambert $P$, Cyna AM, Knight $N$, et al. Clonidine premedication for postoperative analgesia in children. Cochrane database syst rev 2014;1:CD009633.

18. Naja ZM, Khatib R, Ziade FM, et al. Effect of clonidine versus dexmedetomidine on pain control after laparoscopic gastric sleeve: a prospective, randomized, double-blinded study. Saudi J Anaesth 2014;8(Suppl 1):S57-62.

19. Aldrete JA, Krouiik D. A postanaesthetic recovery score. Anesth Analg 1970;49(6):924-34. 